\title{
Knowledge Levels and Attitudes of Emergency Physicians in the province of Ordu about Child Abuse: A Survey Study
}

\author{
(1) Ali Aygün ${ }^{1}$, (1) Hacer Yașar Teke² \\ ${ }^{1}$ Department of Emergency Medicine, Ordu University Faculty of Medicine, Ordu, Turkey \\ 2Department of Forensic Medicine, Ordu University Faculty of Medicine, Ordu, Turkey
}

\begin{abstract}
Aim: The number of studies conducted to find out the knowledge level of emergency physicians in Turkey about child abuse and neglect are limited. In this study, knowledge levels and attitudes of emergency physicians on the issue were assessed within the scope of literature.

Materials and Methods: Male and female physicians who worked in the emergency services of state hospitals in Ordu province provincial directorate of health between the dates 01.06 .2018 and 01.09 .2018 and who volunteered to participate were included in the study. The participants were given a 28-item questionnaire form which assessed the participants' demographic characteristics and their attitudes towards child abuse and "Child Abuse Knowledge scale".

Results: $73.2 \%$ of the physicians who participated in the study were general practitioners, while $26.8 \%$ were emergency medicine specialists. The rate of physicians who came across child abuse cases in the emergency service was found as $57.5 \%$. $86.6 \%$ of the physicians stated that child abuse cases required a multidisciplinary approach.

Conclusion: $88 \%$ of the physicians stated that they did not have any post graduate training on child abuse and most of the physicians stated that their post graduate training was not sufficient. Increasing training about the issue before or after graduation can improve physicians' attitudes and behaviours towards child abuse cases. It will be easier to resolve the incident with a multidisciplinary approach when necessary if physicians make an assessment of child abuse as part of examination in each child they examine.
\end{abstract}

Keywords: Child abuse, child's best interest, emergency service, physician

\section{Introduction}

Child abuse, which is defined by World Health Organization (WHO) as behaviors which are conducted knowingly or unknowingly by an adult, the society or the country, and which negatively affects a child's health, physical and social development, is in its widest sense conducting behaviors which are not accepted in that society to a child by an adult within a specific period of time (1). Child abuse is an important problem that is seen in all parts of the world. Although the type of abuse differs depending on factors such as gender, geographical region, and other factors, it is seen within a wide range of $1-35 \%(1,2)$. While the incidence of child abuse is $10-53 \%$ in Turkey, this rate is around $1-10 \%$ globally (3).
Neglect and abuse are familial function disorders that have multiple psychosocial, individual, and environmental reasons. They are difficult to define, and they require health professionals to be suspicious when they meet the family and the child for the first time (1). Some factors about the health system prevent the patient and the physician from being together within a necessary and extended period of examination, and this makes early diagnosis difficult. This situation can lead to the continuation of neglect/abuse. This way, undiagnosed neglect/abuse causes chronic abuse and increased death and disease rates $(1,4)$. WHO emphasizes that it is among the responsibilities of health professionals to provide a proper diagnosis, protection, and treatment conditions to neglected and abused children (5). It is 
emphasized as an issue in literature for health workers to be aware of the physical and behavioral characteristics of child abuse and to have sufficient proficiency in treating, preventing, and reporting child abuse (6).

In this study, knowledge levels and attitudes of emergency physicians on the issue of child abuse and neglect were assessed within the scope of literature.

\section{Materials and Methods}

\section{Study Design, Population and Data Collection}

Approval was obtained from Ordu University Clinical Researches Ethical Board (decision number: 2018/155) for the study. Male and female physicians who worked in the emergency services of state hospitals in Ordu province provincial directorate of health between the dates 01.06.2018 and 01.09.2018 and who volunteered to participate were included in the study. A total of 10 physicians who did not want to participate in the study and those who filled in the question forms incompletely were excluded.

In addition to a 28-item questionnaire form that assessed participants' demographic characteristics and their attitudes towards children, the "Child Abuse Knowledge scale" with 25 items, which was developed and examined for validity and reliability by Kara et al. (7), was given to the participants. In the knowledge scale, each question included three answers consisting of the words "yes", "no", and "no idea"; the answers to questions 14, 16, 21, and 23 were "no", while the others were "yes". Each correct answer was accepted as " 1 point" and knowledge scores were calculated separately for five sections as "history", "examination", "radiology", "risk groups" and "symptoms". Also, scores of the sections were added, and a total knowledge score was obtained on the issue of child abuse and neglect (7). After the informed consent of the physicians within the sample group was obtained, the questionnaire and the scale were filled in by the physicians who participated in the study. The number of participants in the study was determined to be 125 according to Tavsancil's "sample volume in the scale studies should be at least five times the minimum of each scale item" recommendation (8).

\section{Statistical Analysis}

A statistical package program was used for statistical analysis. Descriptive analysis of assessment results was given as numbers and percentages for categorical variables and as mean, standard deviation, minimum, and maximum for numerical variables. A chi-square test was used for the analysis of categorical variables. Shapiro Wilk test was used to determine the appropriateness of scale scores to a normal distribution. The Mann-Whitney U test was used for non-normally distributed variables between two groups and the Kruskal-Wallis test for non-normally distributed parameters between more than two groups. $\mathrm{p}<0.05$ was considered as statistically significant.

\section{Results}

A total of 127 physicians, 66 (52.0\%) female and 61 (48.0\%) male, participated in the study. The mean age of the physicians was 29.44 \pm 5.42 years (range: $23-54$ ). Forty point two percent of the physicians were married, while $76 \%$ were single, and $28.3 \%$ had children. Seventy-three point two percent of the physicians who participated in the study were general practitioners, while 26.8\% were emergency medicine specialists. In terms of years in the profession, the minimum period in the profession was one year, while the maximum period was 29 years, with an average of $4.98 \pm 4.49$ years. The mean time spent in the emergency service was found as $3.76 \pm 3.74$ years.

While no statistically significant difference was found between general practitioners and specialists in terms of having received forensic medicine education before graduation, the rate of having received training about child abuse was found to be statistically significantly higher in general practitioners when compared with specialists $(p<0.001)$. While physician groups were not homogeneous in terms of pre-graduation training, they formed a homogeneous group in terms of post-graduation training (Table 1).

The rate of physicians who came across child abuse cases was found to be $57.5 \%$. Eight of these physicians stated that they performed a genital examination for sexual abuse cases in the emergency service, and they also stated that they did not experience any problems with the examination. Thirteen point four percent of the physicians stated that the children who referred to emergency service for being poisoned could not be assessed as "child abuse". Eighty-six point six percent of the physicians stated that child abuse cases required a multidisciplinary approach, and $80.8 \%$ thought that child abuse should not be considered as unidimensional and that reports should not be prepared without making the required consultations for the child's examination (pediatric psychiatry, general surgery, pediatric diseases, gynecology, infectious diseases, and forensic science). While $55.9 \%$ of the physicians stated that it would be suitable for child monitoring centres (CMC) to assess all kinds of abuse cases so that child abuse cases could be appropriately assessed, 3.1\% stated that it would be enough for only sexual abuse cases to be assessed at CMC, and other cases could be resolved at emergency services and polyclinics. It was found to be statistically significant that emergency physicians frequently came across child abuse cases $(\boldsymbol{p}<0.001)$. In terms of the 
question of which abuse cases referred to the emergency service the most, both groups answered this question as "neglect" the most and statistically significant difference was found between the two groups $(p=0.005)$. Also, general practitioners answered the question of which abuse group was missed the most in the emergency service due to difficulties of diagnosis as "emotional abuse," and statistically significant difference was found between the answers of both groups $(p=0.027)$ (Table 2$)$. Fifty-nine point

Table 1. Physicians' educational status before and after graduation

\begin{tabular}{|c|c|c|c|}
\hline Physicians' educational status & Specialist (n) & General practitioner (n) & $\mathrm{p}$ \\
\hline Not educated & - & 5 & \multirow{2}{*}{0.168} \\
\hline Educated & 34 & 88 & \\
\hline \multicolumn{4}{|c|}{ Pre-graduation training (child abuse) } \\
\hline Not educated & 17 & 10 & $<0.001$ \\
\hline \multicolumn{4}{|c|}{ Pre-graduation training evaluation } \\
\hline Enough & - & 25 & \multirow{3}{*}{$<0.001$} \\
\hline Partially enough & 15 & 54 & \\
\hline Not enough & 19 & 14 & \\
\hline \multicolumn{4}{|c|}{ Post-graduation training evaluation } \\
\hline Enough & - & 9 & \multirow{3}{*}{0.124} \\
\hline Partially enough & 10 & 31 & \\
\hline Not enough & 24 & 53 & \\
\hline
\end{tabular}

Table 2. Physicians' views and assessments about abuse cases in the emergency service

\begin{tabular}{|c|c|c|c|}
\hline Physicians' views and assessments & Specialist (n) & General practitioner $(\mathrm{n})$ & $\mathrm{p}$ \\
\hline \multicolumn{4}{|c|}{ Encountering with the child abuse cases } \\
\hline Encountered & 31 & 42 & $<0.001$ \\
\hline \multicolumn{4}{|c|}{ The most common type of child abuse cases in the emergency department } \\
\hline Sexual abuse & - & 4 & \multirow{3}{*}{0.005} \\
\hline Physical abuse & 4 & 34 & \\
\hline Neglect & 28 & 44 & \\
\hline \multicolumn{4}{|c|}{ The most common skipped type of child abuse cases in the emergency department } \\
\hline Sexual abuse & 17 & 25 & \multirow{2}{*}{0.027} \\
\hline Emotional abuse & 11 & 55 & \\
\hline Yes & 34 & 76 & \multirow{2}{*}{0.07} \\
\hline No & - & 17 & \\
\hline \multicolumn{4}{|l|}{ Using the form of child abuse } \\
\hline Used & 10 & 25 & \multirow{2}{*}{0.77} \\
\hline Not used & 24 & 68 & \\
\hline
\end{tabular}


eight percent of the physicians stated that when symptoms of child abuse were found in a child who was brought to the emergency service for another reason, they would accept the case as a judicial case, write a judicial report and inform the judicial authorities. Thirty-five point five percent of the participants stated that it would be suitable to get a consultation from physicians such as forensic medicine and pediatric surgery physicians and/ or be supported by organizations such as CMC, etc. and to make a decision afterward. All of the physicians stated that they prepared judicial reports when such cases were defined. Fifteen point seven percent of the physicians stated that there were no criminal sanctions when no reports were made, while others reported that there were criminal sanctions, and $41.7 \%$ stated that this sanction was one year of imprisonment. In terms of the existing legal sanctions in Turkish Penal Code (TPC) about sexual abuse crime conducted against children, $55.1 \%$ of the physicians described these sanctions as mild, while $20.5 \%$ described them as very mild, $15.7 \%$ as sufficient, $3.9 \%$ as severe and $4.7 \%$ as very severe.

It was found that the physicians who participated in the study got a minimum of 11 points from the Child Neglect and Abuse Information scale, while they got a maximum of 25 points. The standard mean of the total scale scores was $20.98 \pm 2.96$, and Table 3 presents the results of physicians' total score averages in terms of some of the characteristics of physicians. In the post hoc test (with Bonferroni), it was seen that total test mean scores were according to the statistically significant low between 34-38 age group of physicians and 23-28 $(p=0.01)$ and 29-33 age groups of physicians $(p=0.03)$. Also, the total test score of the physicians who received pre-graduation child abuse education and found this education to be adequate was found to be statistically higher than the physicians who found it to be inadequate $(p=0.05)$.

Average scores of the subdivisions of Child Neglect and Abuse Information scale were $5.83 \pm 0.46$ for part $1,5.48 \pm 0.76$ for part 2, $2.07 \pm 0.79$ for part $3,4.37 \pm 1.37$ for part 4 and $3.22 \pm 0.92$ for part 5. The distribution of divisional and total points "Child Neglect and Abuse Knowledge scale" received by physicians was showed in Table 4.

\section{Discussion}

In our country where anyone who is younger than 18 years of age is considered as children, child abuse is a significant public health issue with medical, legal, and social aspects, which can cause serious injuries, disabilities, and even death (9-11). Recently, our country lets in too many immigrants, and in complex situations that can develop with the problems of immigrant children, the solution is expected from physicians. Various studies conducted show that the rates of child abuse among judicial cases that refer to emergency services differ between $18-43 \%$ (12-14). In the case of a correct assessment of the symptoms by the physician, the diagnosis of child abuse is considered to be the first step in the solution of the problem.

In a study conducted in the province of Ankara, it was found that $82 \%$ of pediatricians, $70.5 \%$ of pediatrician assistants, and $54.8 \%$ of general practitioners came across abuse and neglect cases or suspicion (9). In a thesis study, it was found that the rate of coming across child abuse and neglect cases in the past year was $21.1 \%$ and that all participants, in general, had a lack of knowledge and experience about child abuse and neglect (15). Similar to other studies, the rate of child abuse in emergency services was found as $53 \%$. In another study conducted in Kuwait, it was found that $14 \%$ of pediatricians did not come across a suspicious child abuse case all through their lives (16). In another study conducted in Sweden, very low rates of cases were found in primary health care providers, and it was even emphasized that a physician who worked more than 30 years did not come across any cases (17). In our study, all of the physicians stated that they reported when cases were diagnosed. Also, while $86.6 \%$ of the physicians in the study group were advocates of a multidisciplinary approach, only $34.6 \%$ stated that they would report after they got the views of related units and polyclinics about child abuse and $55.9 \%$ stated that they would report immediately when they found symptoms of abuse. In another study conducted in our country, $85 \%$ of the physicians stated that they would think about reporting if they came across abuse cases or suspicion (9). In the same study, the reasons why physicians did not report were respectively as follows; not having enough information about child abuse and neglect, not knowing where they should report, not having time to allocate to this issue, security concerns, thinking that the child will get harm later, thinking that the child will be separated from the family and other reasons (9). In a national study conducted in America, it was found that only a small number of pediatricians did not report in cases that had injuries suspicious in terms of child abuse (18-20). The reason why physicians did not report was the fact that a definitive diagnosis was not made for abuse and that they believed the problem could be solved within the family (20). In another study conducted in North Carolina, it was stated that $10 \%$ of the participants did not report suspected child abuse and neglect cases, and the reason for this was the fact that they thought the court was a painful and sad experience for children (21). While physical abuse is a situation which is frequently realized since relatively a higher number of symptoms are together when compared with other types of abuse, it is known that the rates of recognizing physical abuse are lower as long as physical abuse and sexual abuse are a combined component. In our study, physicians stated that the most frequent number of cases (56.6\%) that referred to the emergency service was neglect cases, with physical abuse (29.9\%) as the second most frequent number of cases. 
Table 3. Mean child neglect and abuse knowledge scale scores of the physicians in the study in terms of their specialties

\begin{tabular}{|c|c|c|c|}
\hline Characteristics & $\mathbf{n}$ & Mean \pm SD & $p$ \\
\hline \multicolumn{4}{|l|}{ Sex $^{*}$} \\
\hline Female & 66 & $21.53 \pm 2.85$ & 0.018 \\
\hline \multicolumn{4}{|l|}{ Age* $^{*}$} \\
\hline 23-28 ages & 72 & $21.51 \pm 2.36$ & \multirow{3}{*}{0.017} \\
\hline 34-38 ages & 10 & $18.00 \pm 3.33$ & \\
\hline 31 ages and older & 12 & $19.50 \pm 2.96$ & \\
\hline \multicolumn{4}{|l|}{ Title } \\
\hline General practitioner & 93 & $21.78 \pm 2.80$ & \multirow{2}{*}{0.442} \\
\hline Specialist & 34 & $20.52 \pm 3.36$ & \\
\hline \multicolumn{4}{|l|}{ Child status } \\
\hline Having children & 36 & $20.52 \pm 3.63$ & \multirow{2}{*}{0.712} \\
\hline No children & 91 & $21.16 \pm 2.65$ & \\
\hline \multicolumn{4}{|l|}{ Working time in ED } \\
\hline One year and below & 65 & $21.26 \pm 2.75$ & \multirow{2}{*}{0.386} \\
\hline Two years and over & 62 & $20.69 \pm 3.17$ & \\
\hline \multicolumn{4}{|c|}{ Pre-graduation training } \\
\hline Educated & 100 & $21.26 \pm 2.49$ & 0.362 \\
\hline Not encountered & 54 & $21.14 \pm 2.97$ & 0.482 \\
\hline \multicolumn{4}{|c|}{ Pre-graduation training evaluation* } \\
\hline Enough & 25 & $22.24 \pm 2.89$ & \\
\hline Partially enough & 69 & $20.88 \pm 2.24$ & 0.010 \\
\hline Not enough & 33 & $20.24 \pm 3.98$ & \\
\hline \multicolumn{4}{|c|}{ The most common type of child abuse cases in the ED } \\
\hline Sexual abuse & 4 & $21.25 \pm 2.06$ & \multirow{4}{*}{0.998} \\
\hline Emotional abuse & 13 & $20.84 \pm 2.99$ & \\
\hline Physical abuse & 38 & $21.02 \pm 2.92$ & \\
\hline Neglect & 72 & $20.97 \pm 3.07$ & \\
\hline \multicolumn{4}{|c|}{ The most common skipped type of child abuse cases in the ED } \\
\hline Sexual abuse & 42 & $21.83 \pm 2.12$ & \multirow{4}{*}{0.151} \\
\hline Emotional abuse & 66 & $20.68 \pm 3.30$ & \\
\hline Physical abuse & 6 & $19.33 \pm 3.14$ & \\
\hline Neglect & 13 & $20.53 \pm 3.04$ & \\
\hline
\end{tabular}


Table 4. Distribution of divisional and total points "Child Neglect and Abuse Knowledge scale" received by physicians

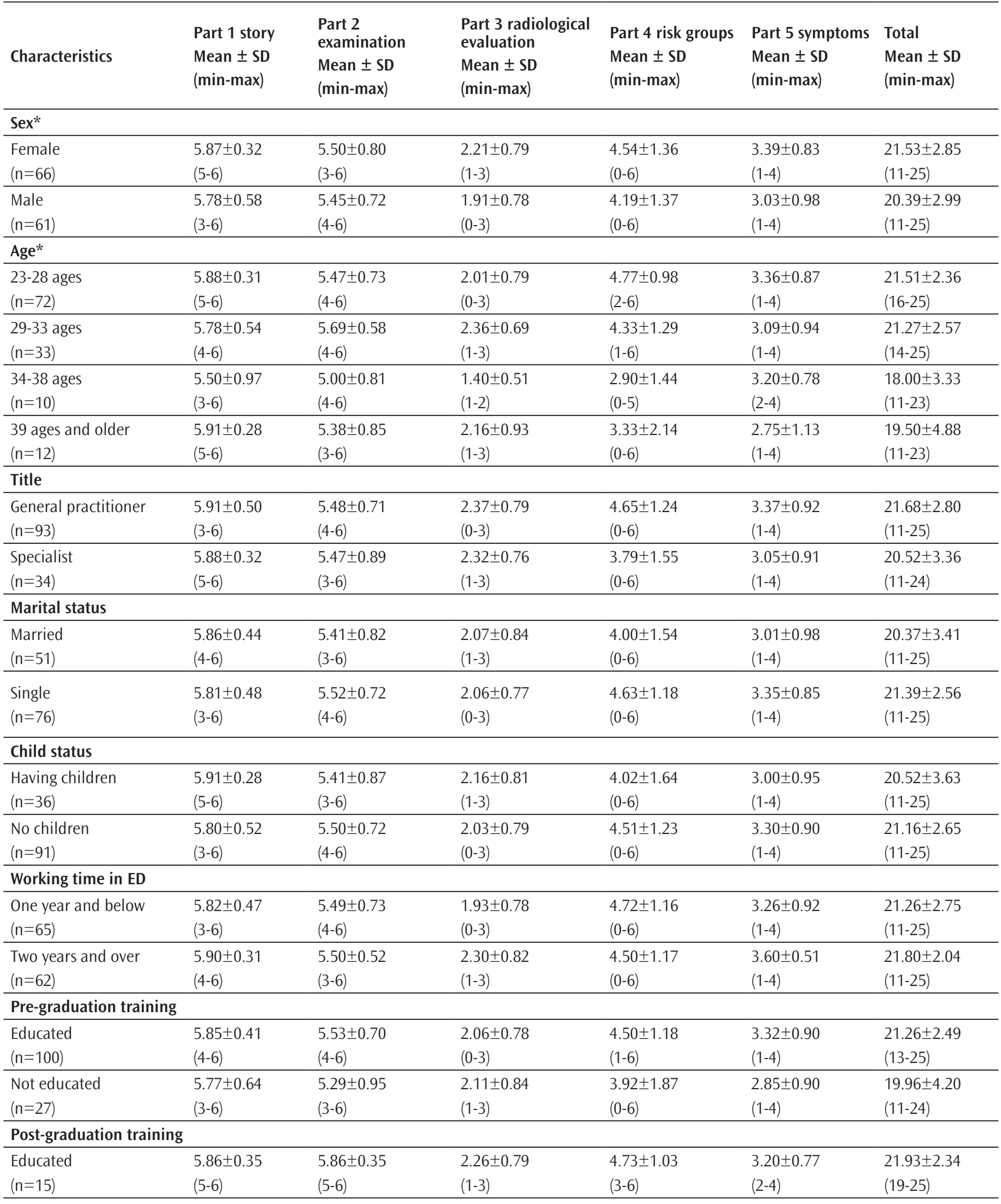


Table 4. contiuned

\begin{tabular}{|c|c|c|c|c|c|c|}
\hline $\begin{array}{l}\text { Not educated } \\
(n=112)\end{array}$ & $\begin{array}{l}5.83 \pm 0.48 \\
(3-6)\end{array}$ & $\begin{array}{l}5.42 \pm 0.79 \\
(3-6)\end{array}$ & $\begin{array}{l}2.04 \pm 0.79 \\
(0-3)\end{array}$ & $\begin{array}{l}4.33 \pm 1.41 \\
(0-6)\end{array}$ & $\begin{array}{l}3.22 \pm 0.94 \\
(1-4)\end{array}$ & $\begin{array}{l}20.85 \pm 3.02 \\
(11-25)\end{array}$ \\
\hline \multicolumn{7}{|c|}{ The situation of encountering cases of child abuse } \\
\hline Encountered $(n=73)$ & $\begin{array}{l}5.84 \pm 0.43 \\
(4-6)\end{array}$ & $\begin{array}{l}5.45 \pm 0.80 \\
(3-6)\end{array}$ & $\begin{array}{l}2.10 \pm 0.79 \\
(1-3)\end{array}$ & $\begin{array}{l}4.23 \pm 1.37 \\
(0-6)\end{array}$ & $\begin{array}{l}3.21 \pm 0.91 \\
(1-4)\end{array}$ & $\begin{array}{l}20.86 \pm 2.97 \\
(11-25)\end{array}$ \\
\hline Not encountered $(n=54)$ & $\begin{array}{l}5.81 \pm 0.51 \\
(3-6)\end{array}$ & $\begin{array}{l}5.51 \pm 0.72 \\
(4-6)\end{array}$ & $\begin{array}{l}2.01 \pm 0.81 \\
(0-3)\end{array}$ & $\begin{array}{l}4.57 \pm 1.35 \\
(0-6)\end{array}$ & $\begin{array}{l}3.22 \pm 0.94 \\
(1-4)\end{array}$ & $\begin{array}{l}21.14 \pm 2.97 \\
(11-25)\end{array}$ \\
\hline \multicolumn{7}{|c|}{ The most common type of child abuse cases in the ED } \\
\hline Sexual abuse $(n=4)$ & $\begin{array}{l}6.00 \pm 0.00 \\
(6-6)\end{array}$ & $\begin{array}{l}5.00 \pm 1.15 \\
(4-6)\end{array}$ & $\begin{array}{l}2.00 \pm 0.81 \\
(1-3)\end{array}$ & $\begin{array}{l}5.00 \pm 1.41 \\
(3-6)\end{array}$ & $\begin{array}{l}3.25 \pm 0.50 \\
(3-4)\end{array}$ & $\begin{array}{l}21.25 \pm 2.06 \\
(19-24)\end{array}$ \\
\hline Emotional abuse $(n=13)$ & $\begin{array}{l}6.00 \pm 0.00 \\
(6-6)\end{array}$ & $\begin{array}{l}5.61 \pm 0.76 \\
(4-6)\end{array}$ & $\begin{array}{l}1.92 \pm 0.75 \\
(1-3)\end{array}$ & $\begin{array}{l}4.23 \pm 1.36 \\
(2-6)\end{array}$ & $\begin{array}{l}3.07 \pm 0.95 \\
(1-4)\end{array}$ & $\begin{array}{l}20.84 \pm 2.99 \\
(16-24)\end{array}$ \\
\hline Physical abuse $(\mathrm{n}=38)$ & $\begin{array}{l}5.76 \pm 0.54 \\
(4-6)\end{array}$ & $\begin{array}{l}5.47 \pm 0.68 \\
(4-6)\end{array}$ & $\begin{array}{l}1.97 \pm 0.85 \\
(1-3)\end{array}$ & $\begin{array}{l}4.36 \pm 1.28 \\
(1-6)\end{array}$ & $\begin{array}{l}3.44 \pm 0.89 \\
(1-4)\end{array}$ & $\begin{array}{l}21.02 \pm 2.92 \\
(13-25)\end{array}$ \\
\hline Neglect $(n=72)$ & $\begin{array}{l}5.83 \pm 0.47 \\
(3-6)\end{array}$ & $\begin{array}{l}5.48 \pm 0.78 \\
(3-6)\end{array}$ & $\begin{array}{l}2.15 \pm 0.78 \\
(0-3)\end{array}$ & $\begin{array}{l}4.37 \pm 1.37 \\
(0-6)\end{array}$ & $\begin{array}{l}3.12 \pm 0.94 \\
(1-4)\end{array}$ & $\begin{array}{l}20.97 \pm 3.07 \\
(11-25)\end{array}$ \\
\hline \multicolumn{7}{|c|}{ The most common skipped type of child abuse cases in the ED } \\
\hline Sexual abuse $(n=42)$ & $\begin{array}{l}5.90 \pm 0.29 \\
(5-6)\end{array}$ & $\begin{array}{l}5.66 \pm 0.65 \\
(4-6)\end{array}$ & $\begin{array}{l}2.40 \pm 0.73 \\
(1-3)\end{array}$ & $\begin{array}{l}4.40 \pm 1.19 \\
(2-6)\end{array}$ & $\begin{array}{l}3.45 \pm 0.83 \\
(1-4)\end{array}$ & $\begin{array}{l}21.83 \pm 2.12 \\
(16-24)\end{array}$ \\
\hline Emotional abuse $(n=66)$ & $\begin{array}{l}5.78 \pm 0.56 \\
(3-6)\end{array}$ & $\begin{array}{l}5.37 \pm 0.81 \\
(3-6)\end{array}$ & $\begin{array}{l}1.93 \pm 0.78 \\
(0-3)\end{array}$ & $\begin{array}{l}4.45 \pm 1.47 \\
(0-6)\end{array}$ & $\begin{array}{l}3.12 \pm 0.98 \\
(1-4)\end{array}$ & $\begin{array}{l}20.68 \pm 3.30 \\
(11-25)\end{array}$ \\
\hline Physical abuse $(n=6)$ & $\begin{array}{l}5.83 \pm 0.40 \\
(5-6)\end{array}$ & $\begin{array}{l}5.16 \pm 0.98 \\
(4-6)\end{array}$ & $\begin{array}{l}1.50 \pm 0.54 \\
(1-2)\end{array}$ & $\begin{array}{l}3.66 \pm 1.50 \\
(2-5)\end{array}$ & $\begin{array}{l}3.16 \pm 0.75 \\
(2-4)\end{array}$ & $\begin{array}{l}19.33 \pm 3.14 \\
(16-23)\end{array}$ \\
\hline Neglect $(n=13)$ & $\begin{array}{l}5.84 \pm 0.37 \\
(5-6)\end{array}$ & $\begin{array}{l}5.53 \pm 0.66 \\
(4-6)\end{array}$ & $\begin{array}{l}1.92 \pm 0.86 \\
(1-3)\end{array}$ & $\begin{array}{l}4.23 \pm 1.36 \\
(1-6)\end{array}$ & $\begin{array}{l}3.00 \pm 0.91 \\
(1-4)\end{array}$ & $\begin{array}{l}20.53 \pm 3.04 \\
(13-24)\end{array}$ \\
\hline
\end{tabular}

In a study they conducted on pediatricians and general practitioners, Kara et al. (7) found similar to the results of our study that the most frequently seen cases were neglect with $45.8 \%$, with physical abuse second most frequently seen with a rate of $23.6 \%$. In our country, child abuse is a judicial case that should be reported when diagnosed, and there is a criminal sanction when it is not reported in terms of health professionals according to the item 280 of TPC. This is defined as one year of imprisonment in the penal code. In our study, while $15.7 \%$ of the physicians stated that there were no criminal sanctions when no reports were made, $41.7 \%$ stated that criminal sanction was one year of imprisonment when no reports were made.

In terms of the question of "your opinions about the existing criminal sanctions in TPC related with sexual abuse crime committed against children", $75.6 \%$ of the physicians stated that they found these sanctions as mild, while $8.6 \%$ stated that they found these sanctions as severe. Trials about abuse crimes for children include applications that cause discussion before society. These discussions sometimes result from the legislation, sometimes from the verdicts and applications of judicial authorities and sometimes from the attitudes of legal structuring (22). Provisions that organize the crimes against sexual immunity in TPC have been exposed to changes many times since 01/06/2005 when TPC came in force. After the Supreme Court canceled item 103/2 of TPC with the justification that "it cannot be said that the amount of penalty specified is in the rate or extent that will allow the purpose aimed to reach with this penalty. Since the rule predicts an excessive sanction as it is, it is against the principle of law and state", item 103/1 was also canceled with similar justifications (23). After this verdict of the Supreme Court, the real question that caused serious discussions was how to approach crime when the offender of the crime was also a child in crimes committed against sexual immunity (22). When considered in terms of this and other aspects, although the law is sufficient, it may be considered as mild by physicians may be due to differences in practice or as a result of decisions made.

In our study, results parallel to the results of the study conducted in Ankara were found in terms of the scores taken from the 
scale (7). It was seen that the scale scores of the female gender and 33 years old and under physician groups were statistically significantly higher in our study. In a study conducted in 1997 in the USA on 393 physicians who were pediatricians, family physicians, and emergency physicians, it was found that adult female participants were more sensitive than male participants in terms of child abuse (24). It is thought that the reason why younger physicians had higher levels of knowledge was the fact that as stated in Demir's thesis, importance and place were given to the issue of "child abuse" in medical faculty curriculums, especially recently (15).

\section{Conclusion}

In conclusion, emergency physicians come across child abuse cases more frequently when compared with general practitioners, and they think that their education about child abuse is insufficient. This questionnaire conducted on emergency physicians in the province of Ordu showed that pre- or post-graduate training conducted on the issue could develop physicians' attitudes and behaviors against child abuse cases. Also, it is an important issue that in-hospital coordination should be built and developed between branches related to the issue and emergency services for the multidisciplinary approach required and considered as necessary by emergency physicians. We believe that assessing for abuse in each child examined and cooperating with the related institutions and physicians when having suspicions on the issue can develop a mechanism that can prevent missing cases.

\section{Ethics}

Ethics Committee Approval: Ethics committee approval was received for this study from the Ordu University Clinical Researches Ethical Board (decision number: 2018/155).

Informed Consent: Written informed consent was obtained from all participants in this study.

Peer-review: Externally and internally peer-reviewed.

\section{Author Contributions}

Concept: A.A, H.Y.T., Design A.A., Data Collection and/or Processing: A.A, H.Y.T., Analysis or Interpretation: A.A, H.Y.T., Literature Search: A.A, H.Y.T., Writing: A.A, H.Y.T.

Conflict of Interest: The authors have no conflict of interest to declare.

Financial Disclosure: The authors declared that this study had received no financial support.

\section{References}

1. Sarı HY, Ardahan E, Öztornacı BÖ. Systematic reviews about child abuse and neglect in last 10 years. TAF Prev Med Bull. 2016;15:501-11.
2. Gilbert R, Widom CS, Browne K, Fergusson D, Webb E, Janson S. Burden and consequences of child maltreatment in high-income countries. Lancet. 2009;373:68-81.

3. Güner iș, Güner S, Şahan MH. Çocuklarda Sosyal ve Medikal Bir Problem; İstismar. Van Tıp Dergisi. 2010;17:108-13.

4. Koc F, Oral R, Butteris R. Missed cases of multiple forms of child abuse and neglect. Int J Psychiatry Med. 2014;47:131-9.

5. Üniversiteler için hastane temelli Çocuk Koruma Merkezleri El Kitabı, Ankara 2010. http://cokmed.org/_ekurs/uploads/4_universiteler_ckm.pdf. Erişim tarihi: 07.07.2014.

6. Pakis I, Demir F, Bektas G, Altun U, Yıldırım S. Investigation of the awareness and knowledge about child abuse and negligence among doctors and nurses working in the east part of Turkey. Rom J Leg Med. 2015;23:151-6.

7. Kara Ö, Çalıșkan D, Suskan E. Ankara Illinde Görev yapan Çocuk Asistanları, Uzmanları ve pratisyen doktorların çocuk istismarı ve ihmali konusunda bilgi düzeyleri ve yaklașımlarının karșılaștııılması. Türk Pediatri Arșivi. 2014;49:57-65

8. Tavsancıl E. Tutumların Ölçülmesi ve SPSS ileri Veri Analizi. 5.Basım. Ankara: Nobel Yayıncilık; 2014.

9. Acehan S, Bilen A, Ay MD, Gülen M, Avcı A, İçme F. Çocuk İstismarı ve İhmalinin Değerlendirilmesi. Arșiv Kaynak Tarama Dergisi. 2013;22:591-614

10. Kara B, Biçer Ü, Gökalp AS. Çocuk istismarı. Çocuk Sağlığı ve Hastalıkları Dergisi. 2004;47:140-51.

11. Ayvaz M, Aksoy MC. Cocuk istismarı ve ihmal. Hacettepe Tıp Dergisi. 2004;35:27-33

12. Çınar O, Acar YA, Çevik E, Bilgiç S, Ak M, Cömert B. Acil Servise başvuran 0-18 yaș grubu adli olguların özellikleri. Anatol J Clin Invest. 2010;4:148-51.

13. Demircan A, Keleș A, Gürbüz N, Bildik F, Aygencel \$̦.G, Doğan NÖ et al. Forensic emergency medicine - six-year experience of 13823 cases in a university emergency department. Turk J Med Sci. 2008;38:567-75.

14. Altun G, Azmak D, Yılmaz A, Yılmaz G. The characteristics of the cases which admitted to emergency department of Trakya Üniversity Medical Faculty. Bulletin of Legal Medicine. 1997;2:62-6.

15. Demir H. Edirne ili aile sağlığı merkezlerinde görevli hekimlerin çocuk istismarı ve inmali hakkında bilgi, farkındalık ve tutumlarının belirlenmesi. Tez yöneticisi: Yrd. Doç.Dr.Ayșe ÇAYLAN, Trakya Üniversitesi Tıp Fakültesi Aile hekimliği Anabilim Dalı, Edirne, 2012.

16. Al-Moosa A, Al-Shaiji J, Al-Fadhlin A, Al-Bayed K, Adib SM. Pediatricians knowledge, attitudes and experience regarding child maltreatment in Kuwait. Child Abuse Negl. 2003;27:1161-78.

17. Borres MP, Hagg A. Child abuse study among swedish physicians and medical students. Pediatr Int. 2007;49:177-82.

18. Flaherty EG., Sege R., Binns HJ., Mattson CL., Christoffel KK. Health care providers' experience reporting child abuse in the primary care setting. Arch Pediatr Adolesc Med. 2000;154:489-93.

19. Zellman GL. Child abuse reporting and failure to report among mandated reporters. J Interpers Violence. 1990;5:3-22.

20. Flaherty EG, Sege R, Price LL, Christoffel KK, Norton DP, O'Connor K. Pediatrician Characteristics Associated with Child Abuse Identification and Reporting: Results from a National Survey of pediatricians. Child Maltreat. 2006;11:361-9.

21. Theodore AD, Runyan DK. A survey of pediatricians' attitudes and experiences with court in cases of child maltreatment. Child Abuse Negl. 2006;30:1353-63.

22. Coşkun A, Coşkun B, Colak B, Taner FG, Aydın M, Acar N, et al. Cocuğun cinsel istismarı suçu ve bu suçun yargılanması ile çocuk koruma sistemine iliş̧in değișiklik önerileri raporu, 2017:7-15. http://web.e-baro.web.tr/uploads/ 41/04032018basınacıklamasıkıtap.pdf. Date of access:03.12.2018

23. Anayasa Mahkemesinin 26/05/2016 gün, 2015/108 Esas ve 2016/46 Karar sayılı hükmü, RG. 26/05/2016, Sayı 29679

24. Marshall WN, Locke C Jr. Statewide Survey of Physician Attitudes to Controversies About Child Abuse. Child Abuse Negl. 1997;21:171-9. 